\title{
The impact of the Minerals and Petroleum Resources Royalty Act on the South African mining industry: a critical analysis
}

P van der Zwan

\section{School of Accounting Sciences \\ Workwell Research Unit, North West University}

P Nel

Department of Taxation University of Pretoria

\begin{abstract}
The Minerals and Petroleum Resources Royalty Act (MPRRA) became effective on 1 March 2010. This legislation may have a significant impact on employment, foreign investment and future exploration in the South African mining industry. This article reports on a critical analysis of the MPRRA prior to its implementation in order to identify aspects that may impact adversely on the South African mining industry and would require further research after the implementation of the MPRRA. Based on the findings, the authors recommend that the impact of the level of royalties levied as well as the mechanism to promote downstream beneficiation be researched to establish whether the legislators ought to reconsider these provisions in the light of their impact on the mining industry.
\end{abstract}

\section{Key words}

Mineral royalties; Mineral Extraction Tax; Mineral and Petroleum Resources Development Act (MPRDA); Mineral and Petroleum Resources Royalty Act (MPRRA); Mineral and Petroleum Resources Royalty Bill (MPRRB)

Acknowledgement of financial support

This study is partially based on a masters degree which was supported by a performance bursary from the University of Pretoria.

\section{Introduction}

Globally, no type of mining tax has caused as much controversy as mineral royalties (Otto et al. 2006:1). The introduction of legislation to impose mineral royalties in South Africa is no exception.

The inauguration of the new political dispensation in South Africa in 1994 initiated a dynamic shift in the ownership, management and development of the country's mineral heritage (Cawood 2004:53. An overall transformation of the national mineral and mining policies resulted in the enactment of the Mineral and Petroleum Resources Development Act (28 of 2002) (MPRDA) in 2002. In accordance with the MPRDA, the country's mineral and petroleum resources are the common heritage of the people of South Africa. The state acts as the custodian of these resources for the benefit of all the people. The MPRDA allows the state, in its capacity as custodian, to determine and levy a fee or consideration payable in respect of these resources. This enabled the National 
Treasury and the Department of Minerals and Energy (DME) (after the development of the MPRRA, the DME was split into the Department of Mineral Resources and the Department of Energy) to develop legislation to impose royalties on the extraction of the country's mineral and petroleum resources. This process culminated in the enactment of the Mineral and Petroleum Resources Royalty Act (28 of 2008) (MPRRA) on 24 November 2008.

The resistance evident in the mining industry on the release of the draft versions of the Minerals and Petroleum Resources Royalty Bill (MPRRB) made apparent the potential impact of this legislation. The industry expressed the view that the proposed regime was inappropriate in a number of key respects (Chamber of Mines of South Africa 2003:4). Despite an extensive process that was followed to develop the MPRRA, the mining industry remains cautious about the impact of the royalties and it has requested that legislators keep an open mind about changing this legislation in future (Stewart 2008). The royalty regime's potentially significant impact was evident when the implementation of the MPRRA was delayed by ten months to assist the mining industry in surviving the global economic crisis and prevent job losses (National Treasury 2009:18).

The Chamber of Mines of South Africa (2009:19) estimates that the mining industry's direct and indirect contribution to the South African economy includes approximately one million employment opportunities, $18 \%$ of the GDP, $18 \%$ of the gross investment in South Africa and 50\% of the country's exports. These statistics show that this industry is a vital component of the South African economy. The introduction of this new tax, which became effective from 1 March 2010, could significantly affect the mining industry, which is particularly sensitive to tax- imposed effects because of its cost structure and vulnerability to market-driven demand and price swings (Otto et al. 2006:xiv). Aspects such as employment opportunities, the international investment attractiveness of the South African mining industry and decisions on the feasibility of future exploration and optimal utilisation of the country's mineral wealth may be affected by the royalty regime.

The research question that arises from the implementation of the MPRRA is whether this legislation could have an unintended adverse impact on the South African mining industry.

Because of the economic significance of this industry and the sensitivity of the industry to the imposition of mining royalties, the purpose of this article is to critically analyse the MPRRA prior to its implementation to identify whether any of its aspects has the potential to have a significant adverse impact on the South African mining industry and would therefore necessitate further research once the regime has been implemented.

The analysis of the MPRRA was conducted in the form of conceptual research. This research methodology was followed because actual data that illustrate the impact of the royalty regime were not available prior to its implementation. This article consists of a comparison of the provisions of the four versions of the MPRRB, a review of the literature available, a quantitative comparison of the application of these provisions to a hypothetical fact pattern and a critical evaluation of key aspects of the MPRRA based on these comparisons. It focuses only on the potential financial and economic implications of the imposition of royalties on the extraction and transfer of mineral and petroleum resources in isolation from other taxes (any reference to mineral resources should be taken to include petroleum resources). 


\section{Background to the analysis of the MPRRA}

The economic impact of the mineral royalty regime depends on the royalty charging provision as well as relief from this royalty. the royalty base to which this rate is applied (Cawood 2007:496). Table 1 provides an overview of the components of the royalty charging and relief provisions in each version of the MPRRB.

\subsection{Overview of the development of the charging and relief provisions}

The royalty charging provision consists of two elements, namely the royalty rate and

Table 1 An overview of the development of the MPRRA's charging and relief provisions

\begin{tabular}{|c|c|c|c|c|}
\hline & $\begin{array}{c}\text { 1st draft bill } \\
\text { (South Africa 2003) }\end{array}$ & $\begin{array}{c}\text { 2nd draft bill } \\
\text { (South Africa 2006) }\end{array}$ & $\begin{array}{c}\text { 3rd draft bill } \\
\text { (South Africa 2007) }\end{array}$ & $\begin{array}{c}\text { Final bill (MPRRA) } \\
\text { (South Africa } \\
\text { 2008a, South Africa } \\
\text { 2008b) }\end{array}$ \\
\hline $\begin{array}{l}\text { Royalty } \\
\text { base }\end{array}$ & $\begin{array}{l}\text { Published tradable } \\
\text { value that reflects the } \\
\text { arm's length price of } \\
\text { the mineral resource } \\
\text { transferred (gross } \\
\text { sales value if } \\
\text { published value not } \\
\text { available) }\end{array}$ & $\begin{array}{l}\text { Gross sales value of } \\
\text { mineral resource } \\
\text { transferred }\end{array}$ & $\begin{array}{l}\text { Gross sales value } \\
\text { less allowable } \\
\text { deductions (including } \\
\text { a deduction for } \\
\text { processing costs } \\
\text { incurred beyond the } \\
\text { initial readily saleable } \\
\text { condition of the } \\
\text { mineral resource) } \\
\end{array}$ & $\begin{array}{l}\text { Gross sales value of } \\
\text { mineral resource } \\
\text { transferred }\end{array}$ \\
\hline Royalty rate & $\begin{array}{l}\text { Fixed rate prescribed } \\
\text { per category of mineral } \\
\text { (ranging between } 1 \\
\text { and } 8 \% \text { ); } \\
\text { Discrimination } \\
\text { between } 10 \text { groups of } \\
\text { mineral resources }\end{array}$ & $\begin{array}{l}\text { Fixed rate prescribed } \\
\text { per category of } \\
\text { mineral (ranging } \\
\text { between } 0 \text { and } 6 \% \text { ); } \\
\text { Discrimination } \\
\text { between } 11 \text { groups of } \\
\text { minerals as well as } \\
\text { refined and unrefined } \\
\text { mineral resources for } \\
\text { certain minerals }\end{array}$ & $\begin{array}{l}\text { Rate determined in } \\
\text { terms of a formula }{ }^{1} \\
\text { driven by extractor's } \\
\text { profitability (EBITDA); } \\
\text { Uniform formula for all } \\
\text { mineral resources }\end{array}$ & $\begin{array}{l}\text { Rate determined in } \\
\text { terms of a formula } \\
\text { driven by extractor's } \\
\text { profitability (EBIT) } \\
\text { subject to minimum } \\
\text { and maximum level; } \\
\text { Different formulas for } \\
\text { refined and unrefined } \\
\text { mineral resources }\end{array}$ \\
\hline \multicolumn{5}{|c|}{ Relief provisions } \\
\hline $\begin{array}{l}\text { Marginal } \\
\text { mine relief }\end{array}$ & $\begin{array}{l}\text { Marginal mine relief } \\
\text { available to low-grade } \\
\text { mines at the discretion } \\
\text { of the Minister }\end{array}$ & $\begin{array}{l}\text { Marginal mine relief } \\
\text { based on the net } \\
\text { adjusted turnover of } \\
\text { the extractor }\end{array}$ & $\begin{array}{l}\text { Rate formula } \\
\text { provided automatic } \\
\text { profitability relief to } \\
\text { marginal mines }\end{array}$ & $\begin{array}{l}\text { Rate formula } \\
\text { provided automatic } \\
\text { profitability relief to } \\
\text { marginal mines }\end{array}$ \\
\hline $\begin{array}{l}\text { Fiscal } \\
\text { stability }\end{array}$ & $\begin{array}{l}\text { Fiscal stabilisation } \\
\text { clause that fixed the } \\
\text { royalty rate at a higher } \\
\text { rate than the } \\
\text { proposed rates }\end{array}$ & $\begin{array}{l}\text { Royalty rate } \\
\text { guarantee that fixes } \\
\text { the royalty rates at } \\
\text { current levels }\end{array}$ & $\begin{array}{l}\text { Fiscal guarantee } \\
\text { agreement entered } \\
\text { into with extractors to } \\
\text { ensure that } \\
\text { extractors will not be } \\
\text { affected by certain } \\
\text { changes in legislation }\end{array}$ & $\begin{array}{l}\text { Fiscal guarantee } \\
\text { agreement entered } \\
\text { into with extractors } \\
\text { to ensure that } \\
\text { extractors will not be } \\
\text { affected by changes } \\
\text { in rate formula }\end{array}$ \\
\hline $\begin{array}{l}\text { Relief to } \\
\text { smaller and } \\
\text { start-up } \\
\text { mining } \\
\text { enterprises }\end{array}$ & None & $\begin{array}{l}\text { Small mining } \\
\text { business relief that } \\
\text { exempts small mining } \\
\text { businesses from the } \\
\text { first R50 } 000 \\
\text { royalties }\end{array}$ & $\begin{array}{l}\text { Small mining } \\
\text { business exemption } \\
\text { from royalties if } \\
\text { royalty amount is } \\
\text { below R50 } 000 \text { per } \\
\text { assessment period ( } 6 \\
\text { months) }\end{array}$ & $\begin{array}{l}\text { Small mining } \\
\text { business exemption } \\
\text { from royalties if } \\
\text { royalty amount is } \\
\text { below R100 } 000 \text { p.a. }\end{array}$ \\
\hline
\end{tabular}




\section{Notes to table 1}

1 The third draft bill proposed the following formula to determine the royalty rate: $Y=\frac{X}{B} \times 100$

where the inputs were

$\mathrm{Y}=$ royalty rate

$X=$ earnings before interest, tax, depreciation and amortisation (EBITDA) divided by aggregated gross sales for the assessment period (this will be a net profit ratio)

$B=$ fixed input of 12.5

2 The final bill proposed the following formulas to determine the royalty rate for refined and unrefined minerals respectively: (where EBIT = earnings before interest and taxes determined as gross sales less allowable deductions determined in terms of the Income Tax Act (58 of 1962))

$$
\begin{aligned}
& \text { Refined minerals }(\mathrm{s} 4(1)): 0.5+\left(\frac{\text { EBIT for refined minerals }}{\text { Gross sales of refined minerals } \times 12.5(\mathrm{~B}-\text { factor })} \times 100\right) \\
& \text { Unrefined minerals }(\mathrm{s} 4(2)): 0.5+\left(\frac{\text { EBIT for unrefined minerals }}{\text { Gross sales of unrefined minerals } \times 9 \text { (B-factor) }} \times 100\right)
\end{aligned}
$$

The research question to be evaluated is whether the evolution of these provisions, as illustrated in table 1 , resulted in legislation that will achieve its objectives, which are discussed below. If the legislation does not achieve these objectives, it may have an unintended adverse impact on the mining industry.

\subsection{Aspects of the MPRRA that were evaluated in the analysis}

Mineral royalties are levied to provide compensation to the owners of mineral resources for the depletion of their nonrenewable resources by mining companies (Otto et al. 2006:41). The analysis of South Africa's royalty regime had to be performed from the perspective of both parties affected by this royalty instrument, namely the owner and the private mineral extractor, because this tax will influence their economic decisions and behaviour.

The objective of the owner of the mineral resources is to collect a fair compensation for the depletion of his or her nonrenewable mineral resources. If the mineral resources are owned by the state, as in South Africa, the level of this compensation should be sufficient to enable the state to achieve its broader economic and social objectives (Sharma \& Naresh 2001:3). The level of royalty to be levied in terms of the MPRRA therefore needed to be evaluated from the perspective of the owner of the mineral resources. This compensation should, however, not be levied at such a high rate that it discourages mining companies to extract the resources because this will eradicate the owner's income stream in the long run (Otto et al. 2006:64). In addition to the level of royalties, it was therefore necessary to evaluate whether the royalty regime balances the fiscal risk between the state and the extractor in such a way that exploration is encouraged to generate revenue to be used to achieve the state's broader objectives. One such broad objective in South Africa is the need to transform society from being racially exclusive into one that allows full participation of all its members (SAMDA 2003:4). The introduction of mineral royalties could add another barrier to entry into mining ventures and could threaten the viability of many BEE projects that facilitate transformation (Competition Commission 2003:1). Another broad objective explicitly stated in the Minerals and Mining Policy for South Africa (Department of Minerals and Energy 1998) is that the South African mining industry should be a competitive investment 
destination for foreign investors. The level and stability of a mineral royalty regime could impact on South Africa's attractiveness as a mining investment destination in a developing country (Andrews-Speed \& Rogers 1999:221). The analysis therefore had to investigate whether the royalty legislation encourages and supports these initiatives by providing relief and stability where it may be necessary. Lastly, the state, as custodian of the nation's mineral resources, has the responsibility of ensuring that the national wealth obtained from these nonrenewable resources is maximised. The benefit derived from the exploration of the country's nonrenewable mineral resources can be maximised when value is added by further processing (referred to as downstream beneficiation) before the resources are transferred (Department of Minerals and Energy 1998). The analysis therefore had to evaluate how the royalty regime will impact on the promotion of downstream beneficiation.

According to economic principles, the private mining extractor's decision whether mineral resources should be explored or extracted will be driven by a profit motive (Otto et al. 2006:64). If the level of compensation sought by the owner of the mineral resources is too high, this will discourage exploration and lead to the premature abandonment of the mineral deposits (O'Faircheallaigh 1998:189). In order to encourage exploration, the mineral extraction tax should take into account the benefits received by the extractor, that is, the profit realised, as a result of extracting the mineral resources. Hence the level of royalties and balance of the fiscal risk need to be evaluated from the extractor's perspective.

Based on these stated objectives of the stakeholders, the following aspects of the royalty charging and relief provisions of the MPRRA were critically analysed, as indicated in the next section of this article:

$\square$ the level of the royalties to be levied (3.1)

$\square$ the balance between state revenue and encouraging exploration of reserves (3.2)

$\square$ the relief and stability provided to mineral extractors (3.3)

$\square$ the impact of the royalty regime on the promotion of downstream beneficiation (3.4)

\section{Critical analysis of the MPRRA}

\subsection{The level of royalties to be levied}

As stated earlier, the overall level of the royalty levied depends on the royalty base as well as the royalty rate. Table 2 provides a comparison of these inputs for each version of the MPRRB.

Table 2 Comparison of the factors impacting on the expected overall level of royalties for each version of the MPRRB

\begin{tabular}{|l|l|l|l|l|}
\hline & \multicolumn{1}{|c|}{ 1st draft bill } & \multicolumn{1}{|c|}{ 2nd draft bill } & \multicolumn{1}{c|}{ 3rd draft bill } & Final bill (MPRRA) \\
\hline $\begin{array}{l}\text { Substance of } \\
\text { the royalty base }\end{array}$ & $\begin{array}{l}\text { Sales value of } \\
\text { mineral transferred }\end{array}$ & $\begin{array}{l}\text { Sales value of } \\
\text { mineral transferred }\end{array}$ & $\begin{array}{l}\text { Estimate of value of } \\
\text { mineral when } \\
\text { extracted }\end{array}$ & $\begin{array}{l}\text { Sales value of } \\
\text { mineral transferred }\end{array}$ \\
\hline $\begin{array}{l}\text { Estimated } \\
\text { average level of } \\
\text { royalty rates }\end{array}$ & $\begin{array}{l}1-8 \% \text {, depending } \\
\text { on category of } \\
\text { mineral resource } \\
\text { (First Schedule of } \\
\text { first draft bill) }\end{array}$ & $\begin{array}{l}\text { 0-6\%, depending on } \\
\text { category of mineral } \\
\text { resource (First } \\
\text { Schedule of second } \\
\text { draft bill) }\end{array}$ & $\begin{array}{l}\text { Average 2.6\%, based } \\
\text { on average 2006 \& } \\
\text { 2007 figures for a } \\
\text { sample of companies } \\
\text { (Cawood 2008) }\end{array}$ & $\begin{array}{l}\text { Between 2 and 4\% } \\
\text { on average, based } \\
\text { on historical EBIT } \\
\text { data for 2007 \& 2008 } \\
\text { (National } \\
\text { Treasury 2008b) }\end{array}$ \\
\hline
\end{tabular}


The application of the charging provision and the resultant level of royalty can be illustrated for discussion purposes by the following hypothetical financial information (provided in table 3) for one tonne of platinum group metal (PGM) ore that is extracted. The royalties payable on the transfer of the refined and unrefined PGM under each version of the MPRRB are compared in table 4.

Table 3 Hypothetical financial information used to calculate the royalties under each bill for discussion purposes in the analysis

\begin{tabular}{|c|c|c|}
\hline & $\begin{array}{l}\text { Unrefined } \\
\text { PGM }\end{array}$ & $\begin{array}{l}\text { Refined } \\
\text { PGM }\end{array}$ \\
\hline Gross sales value & $\mathrm{R} 1500$ & R3 200 \\
\hline Extraction costs (excl. depreciation) & (R900) & (R900) \\
\hline Processing costs (excl. depreciation) & - & $(\mathrm{R} 800)$ \\
\hline $\begin{array}{l}\text { Earnings before interest, tax, depreciation and amortisation } \\
\text { (EBITDA) }\end{array}$ & $\mathbf{R} 600$ & R1 500 \\
\hline $\begin{array}{l}\text { Depreciation (assumed to be the same in terms of the Income Tax } \\
\text { Act as the financial reporting framework) }\end{array}$ & (R300) & (R500) \\
\hline Earnings before interest and tax (EBIT) ${ }^{1}$ & R300 & R1 000 \\
\hline
\end{tabular}

1 These EBIT amounts as a percentage of gross sales value are in line with the 20 to $30 \%$ historical ratios that were made available by Statistics SA (National Treasury 2008b:3)

Table 4 Royalty payable on the transfer of the PGM under each version of the MPRRB

\begin{tabular}{|l|c|c|c|c|}
\hline \multirow{2}{*}{} & 1st draft bill & 2nd draft bill & 3rd draft bill & Final bill (MPRRA) \\
\cline { 2 - 5 } & \multicolumn{2}{|c|}{ Royalties payable if the unrefined PGM ore is transferred by } \\
the extractor
\end{tabular}

1 Calculated as gross sales value (R3 200) less processing cost incurred (R800).

Comparison of the level of royalty rates with internationally competitive rates

When the first draft bill was released, the National Treasury (2003:3) indicated that the proposed royalty rates were reasonable and in the lower half of the international rate scale. However, the mining industry noted that the international rates referred to were applied to a lower profit royalty base as opposed to the proposed gross sales value (SAMDA 2003:14). Cawood and Macfarlane (2003:220) investigated mineral royalty rates in developing countries with internationally competitive tax regimes. 
They found that the royalty rates in these countries ranged between 0 and $3 \%$ (on average $1.8 \%$ ) to be applied to a net smelter value, which is a lower base than the sales value if minerals are refined after extraction. They were of the opinion that a royalty levied at a rate exceeding $3 \%$ of the net smelter value could result in a significant additional cost that would have an adverse impact on mining project feasibility. As illustrated in tables 2 and 4, the proposed rates in the first draft bill as a percentage of gross sales value exceeded these thresholds by a significant margin. Even though the level of royalty rates for most categories of minerals in the second draft bill showed a distinct decreasing tendency when compared to the first draft bill, the rate for certain mineral resources increased (e.g. PGMs). The proposed rates still exceeded the internationally competitive rates.

As indicated in table 1 , the level of the royalty rate in the third draft bill was determined by the B-value input as well as by the extractor's profitability. The B-value provided the legislator with a flexible input that could easily be amended to change the level of the royalties levied if it was required to do so. The National Treasury (2008a:7) indicated that the B-value of 12.5 was set in such a way that the royalty rate should vary between 1 and $5 \%$, with an average rate of $2.7 \%$, if the profitability factor ( $\mathrm{X}$ in the royalty rate formula) was between 10 and $60 \%$. Under favourable economic conditions these rates could increase to an absolute maximum of $8 \%$ (1/12.5), even though this was virtually impossible. The Chamber of Mines indicated that a B-value of approximately 20 would result in similar rates to those proposed in the second draft bill (National Treasury 2008a:8), implying that the average rate in terms of the formula (with a B-value of 12.5) was expected to increase from that indicated in the previous draft bill. Private mining companies such as Implats and De Beers shared this expectation (National Treasury 2008a:8). The increase in the royalty rate had to be viewed - and could possibly be justified in the context of the reduction in the royalty base to a significantly lower royalty base. As illustrated in table 4, the overall level of royalties under the third draft bill showed a distinct decreasing trend from the previous two versions of the bill even though the expectation existed that the rates would increase in future in times of economic prosperity. The royalty as a percentage of gross sales value still exceeded the internationally competitive average rate of $1.8 \%$ and appeared to be in the upper end of the scale.

The final bill returned to a gross sales value royalty base and retained the profitability-based royalty rate formula. It did, however, provide a B-value of 12.5 for refined minerals and a more onerous $\mathrm{B}$ value of 9 for unrefined minerals. The royalty rate was capped at $5 \%$ for refined minerals and $7 \%$ for unrefined minerals. Royalty rates that reach the maximum levels could exceed the average royalty rate indicated by the competitive investment framework study by three to four times during times of economic prosperity. Tables 2 and 4 show that the overall level of royalties to be levied in terms of the MPRRA still exceeds the internationally competitive average rate of $1.8 \%$.

\section{Relative portion of profits to be consumed by the royalties}

Earnings before interest and tax (EBIT) is an indicator of the profitability of an extractor - in other words, the benefit that the extractor will receive for his or her efforts. According to Statistics SA, the EBIT/gross sales ratio of mineral extractors, as required for the royalty rate calculation in the final MPRRA, has historically ranged between 20 and $30 \%$ 
(National Treasury 2008b:3). This EBIT ratio will result in expected royalty rates between 2 and $4 \%$. This implies that an extractor's EBIT is likely to be reduced by between $10 \%$ [calculated as: $2 \%$ (royalty) $/ 20 \%($ EBIT)] and $13 \%$ [calculated as: $4 \%$ (royalty) $30 \%$ (EBIT)]. This estimate is confirmed by the royalties under the final MPRRA as a percentage of EBIT in table 4. This reduction in profit is further evidenced by the simplified charging formulae which show that the royalty is largely based on EBIT as opposed to the gross sales value:

$$
\begin{aligned}
\text { Royalty (refined minerals) } & =\text { Gross sales }(S) \times\left[0.5 \%+\left(\frac{\text { EBIT }}{S \times(12.5)}\right) \times 100\right] \\
& =(0.5 \% \times S)+\left(\text { EBIT } \times \frac{1}{12.5}\right) \times 100 \\
& =(\mathbf{0 . 5} \% \times \text { S })+(\text { EBIT } \times \mathbf{8} \%) \\
\text { Royalty (unrefined minerals) } & =\text { Gross sales }(S) \times\left[0.5 \%+\left(\frac{\text { EBIT }}{S \times(9)}\right) \times 100\right] \\
& =(0.5 \% \times S)+\left(\text { EBIT } \times \frac{1}{12.5}\right) \times 100 \\
& =(\mathbf{0 . 5} \% \times \text { S })+(\text { EBIT } \times 11.11 \%)
\end{aligned}
$$

\section{Findings}

Tables 2 and 4 indicate that the expected level of royalty rates has shown a distinctly decreasing trend. However, table 4 indicates that the level of the overall royalty is affected by whether or not the mineral has been refined. This issue is discussed in section 3.4 as it impacts on downstream beneficiation. As indicated in tables 2 and 4 , the average royalty levied is likely to be between 2 and $4 \%$ of the gross sales value of the mineral transferred. This exceeds the average internationally competitive royalty rate of $1.8 \%$ of a net smelter base suggested by Cawood and Macfarlane in 2003. Table 4 and the simplified royalty charging formula indicate that the royalty is likely to reduce the mineral extractor's profit before tax by between 10 and $14 \%$. It is questionable whether the mining industry would be able to absorb a reduction in its profits of this magnitude and whether this royalty regime will be internationally competitive.

\subsection{The balance between state revenue and encouraging exploration of reserves}

A mineral extraction tax system should aim at achieving an optimal trade-off between earning large revenues for the owner, on the one hand, and encouraging mining projects and extraction of mineral resources by private extractors, on the other (Garnaut \& Clunnies Ross 1983:1). This optimal tradeoff will be achieved if the fiscal risk associated with the royalty is shared equitably between the owner and the extractor (Otto et al. 2006:261). The owner bears the fiscal risk when the mineral resources can be depleted for no compensation. The extractor bears the fiscal risk if the extractor is required to pay a royalty irrespective of the benefit (profits) 
obtained from extracting the minerals.

The royalty under the first draft bill, which was based on the tradable value of the mineral resources, resulted in the extractor having to bear most of the fiscal risk because the profit realised by the extractor was ignored. This unbalanced burden could have been too great to absorb, especially for smaller mining companies and BEE participants (SAMDA 2003:6). The introduction of a profitability-based marginal mine relief in the second draft bill shifted the balance of the fiscal risk to a small extent because the availability of the relief measure was limited to extractors on the verge of becoming loss makers (see section 3.3).

The introduction of a single formuladriven royalty rate in the third draft bill provided automatic relief to all extractors, depending on the EBITDA ratio achieved by the extraction. This linked the royalty directly to the extractor's ability to pay it. The formula resulted in a shift of fiscal risk from the mining companies towards the state, as mineral resources could now be extracted at no compensation when the extractor realised no profit from the extraction (National Treasury 2008a:10). Concerns were raised that the charging provision in the third draft bill would disturb the fiscal risk balance (National Treasury 2008a:10). The concern about the fiscal risk balance can be illustrated when the royalty equation is mathematically simplified (Revenue Watch Institute 2008:2):

$$
\text { Royalty }=\text { tax base } x \text { royalty rate }=(S-A) \times \frac{\text { EBITDA }}{(S \times 12.5)}=\frac{(S-A) \times(E B I T D A)}{(S \times 12.5)}
$$

where: $S=$ gross sales

$$
\mathrm{A}=\text { allowable deductions }
$$

This equation demonstrates that the royalty is a product of two inputs, each of which reflects profitability and economic conditions ([S-A] and EBITDA). The profitability and economic conditions are consequently reflected exponentially in the royalty amount. This will lead to the undesired result of exceptionally high royalties in times of economic prosperity (unfavourable for the extractor) and exceptionally low royalties in times of economic difficulties (unfavourable for the state). This imbalance of the fiscal risk balance, however, was restored in the final bill by returning to a gross sales value base, thereby removing profitability from the royalty base, while the profit-driven rate formula was retained. In addition, minimum and maximum rates were introduced to limit the exposure of the parties to the extreme thresholds of the rate formula.

\section{Findings}

The formula of the charging provision encourages exploration by taking into account the extractor's profitability, at the same time ensuring that the nation receives compensation when these mineral resources are depleted by requiring a minimum royalty. In addition, no party is exponentially exposed to the fiscal risk. The fiscal risk of the royalty in the MPRRA is therefore well balanced between the state and extractors. This should encourage extractors to explore mineral resources. Despite this finding, the level of royalties discussed in 3.1 could discourage exploration. 


\subsection{Relief and stability provided to mineral extractors}

A balance had to be struck between upholding the principle of levying a royalty and applying the royalty in a way that it did not trigger detrimental socioeconomic consequences (COSATU/NUM 2003). To achieve this balance, the MPRRA included certain relief provisions.

\section{Relief provided to marginal mines}

Mining enterprises that operate at a low profit margin play a vital role in providing employment and infrastructure to communities. The initial MPRRB equated a marginal mine with a low-grade mine, as opposed to a mine operating at a low profit margin (SAMDA 2003:14). In addition, the significant degree of subjectivity involved in the availability of this measure could have caused inequalities and instability in the regime (Cawood \& Macfarlane 2003:223). The provision evolved into a profitability-linked royalty reduction of up to $75 \%$ of the royalty based on a measurable uniform threshold, namely the extractor's net adjusted cash flow (Cawood 2007:497). The criterion that had to be met to utilise this relief (royalty payable had to exceed the net adjusted cash flow) implied that only entities that were extremely close to the economic break-even point prior to the royalty regime would benefit from this. The royalty rate formula in the last two bills automatically provided relief to marginal mines with lower profit margins because the royalty rate took into account the extractor's profitability. The final bill acknowledges the capital-intensive nature of the mining industry by using EBIT (which allows a deduction for capital expenditure) as a profitability indicator, as opposed to EBITDA (which does not allow for a deduction of depreciation and amortisation) that was proposed in the third draft bill (National Treasury 2008a:8).

\section{Stability of the royalty regime}

The stability of a royalty regime affects its international competitiveness. Providing extractors with an option to fix royalty rates at a higher rate for a specified period, as proposed in the first draft bill, created the expectation of an unstable regime with the anticipation of future increases in royalty rates (Cawood \& Macfarlane 2003:223). The second draft bill proposed that royalty rates be fixed at their current levels for the duration of the mineral right to improve investor confidence in the regime (Cawood 2007:498). This relief measure evolved to allow private binding agreements between the DME and extractors. These agreements would result in a stable yet flexible system by providing a guarantee that adverse changes in the royalty rate formula would not affect the extractor for the duration of the term of a mining right, while other provisions of the MPRRA would be available to the state to amend the royalty regime if the need were to arise (Revenue Watch Institute 2008).

\section{Relief to small mining businesses}

In the South African context it is of critical importance to provide relief to small mining businesses. The South African mining charter specifically requires that opportunities should be extended for previously disadvantaged persons in the mining industry. These opportunities include participation in the mining industry by entities owned by historically disadvantaged persons, who often participate through small mining businesses (SAMDA 2003:5). An exemption from the first R50 000 royalties per assessment period was introduced in the second draft bill to small mining businesses, as defined in the MPRRB, to stimulate and assist them (Cawood 2007:497). This relief developed into a hard cut-off provision in the third draft bill that provided an exemption from the royalties, as long as the total royalty did 
not exceed R50 000 for an assessment period of six months. The principles of the third draft bill were retained in the MPRRA by providing relief if the royalty for a year of assessment of a qualifying extractor does not exceed R100 000. If the royalty rates of between 2 and $4 \%$ in the MPRRA (as per table 2) are applied to this threshold, extractors whose annual revenue is between R2.5 and R5 million would be able to utilise this exemption. According to SAMDA (2003:6), its small-scale members generated revenues between R500 000 and R30 million per annum. The scope of this relief measure is therefore sufficient to cover the lower range of SAMDA's small mining members and should serve its purpose while ensuring that the nation's reserves are not depleted without compensation.

\section{Findings}

Overall, it appears that the royalty regime will provide a stable regime with sufficient relief to start-up activities, small-scale mining activities and marginally profitable extractors.

\subsection{The impact of the royalty regime on the promotion of downstream beneficiation}

A mineral royalty is defined as compensation for the depletion of a nonrenewable mineral resource paid to the owner of the nonrenewable resources (Otto et al. 2006:41). The royalty on the mineral resource that has been extracted should therefore not be affected by events after extraction, such as refinement. The royalty on the refined and unrefined mineral resource should therefore be the same. The royalties payable on the unrefined and refined mineral resource under each version of the draft bill, using the hypothetical fact pattern in table 3 , are compared in table 5.

Table 5 Comparison of royalties on the same mineral resource before and after refinement

\begin{tabular}{|l|c|c|c|c|}
\hline & $\begin{array}{c}\text { 1st draft } \\
\text { bill }\end{array}$ & $\begin{array}{c}\text { 2nd draft } \\
\text { bill }\end{array}$ & $\begin{array}{c}\text { 3rd draft } \\
\text { bill }\end{array}$ & $\begin{array}{c}\text { Final bill } \\
\text { (MPRRA) }\end{array}$ \\
\hline $\begin{array}{l}\text { Royalty on transfer of unrefined mineral resource } \\
\text { (table 4) }\end{array}$ & $R 60$ & $R 90$ & $R 48$ & $R 41$ \\
\hline $\begin{array}{l}\text { Royalty on transfer of refined mineral resource } \\
\text { (table 4) }\end{array}$ & $R 128$ & $R 96$ & $R 90$ & $R 96$ \\
\hline Additional royalty as result of refinement & $\mathbf{R 6 8}$ & $\mathbf{R 6}$ & $\mathbf{R 4 2}$ & $\mathbf{R 5 5}$ \\
\hline
\end{tabular}

The results in table 5 reveal that the royalties on refined mineral resources are significantly higher than those on unrefined mineral resources in the hypothetical fact pattern. This is not the desired outcome because the royalty compensates the owner for the extraction of the same mineral resource in both instances. If the royalty amount increases merely because a mineral resource has been processed, this increase in the royalty could discourage extractors from further processing the minerals that have been extracted and could therefore be in conflict with the mineral policies.

According to Cawood and Macfarlane (2003:215), the first draft bill did not consider downstream beneficiation. Legislators acknowledged this matter as a valid concern and proposed to address it by incorporating the measures into the bills, as summarised in table 6 . 
Table 6 Measures incorporated into the last three versions of the MPRRB to promote downstream beneficiation

\begin{tabular}{|l|l|l|l|}
\hline & \multicolumn{1}{|c|}{ 2nd draft bill } & \multicolumn{1}{c|}{ 3rd draft bill } & \multicolumn{1}{c|}{ Final bill (MPRRA) } \\
\hline $\begin{array}{l}\text { Proposed } \\
\text { measure }\end{array}$ & $\begin{array}{l}\text { Lower royalty rates } \\
\text { provided for refined } \\
\text { minerals }\end{array}$ & $\begin{array}{l}\text { Allow deduction of } \\
\text { processing costs from } \\
\text { royalty base }\end{array}$ & $\begin{array}{l}\text { Lower royalty rates } \\
\text { provided for refined } \\
\text { minerals }\end{array}$ \\
\hline
\end{tabular}

Each of these measures has certain implications for the royalty regime, as elucidated below.

\section{Lower royalty rates for refined mineral resources}

By prescribing a lower royalty rate for refined mineral resources, the legislator attempted to compensate the extractor for the increase in royalty base as a result of beneficiation to arrive at a royalty amount similar to that of an unrefined mineral resource.

The second draft bill provided royalty rates for refined mineral resources that were equal to $50 \%$ of the rate for the unrefined mineral resource. In the hypothetical example, the additional royalty payable decreased from R68 under the first draft bill to R6 under the second draft bill. The reason for the additional R6 reveals the flaw in this approach. The R6 arose because the gross sales value of the mineral resource increased by $113 \%$ (more than doubled) from R1 500 to R3 200, while the royalty rate was reduced by only $50 \%$ (halved). This implies that in order to achieve its objective, the differential between the royalty rate for unrefined and refined mineral resources should consider changes in the gross sales value and EBIT as a result of refinement. It is therefore unlikely that the same royalty on unrefined and refined mineral resources will be achieved by prescribing fixed royalty rates because these variables are not taken into account.

A similar approach was followed in the final bill (MPRRA), except for the introduction of the EBIT/gross sales ratio after further processing into the equation to determine the royalty rate. The refined royalty rate was lower than the unrefined royalty rate as a result of the use of a higher $\mathrm{B}$-value for refined minerals (12.5) than for unrefined minerals (9). This has resulted in a refined rate that is approximately $72 \%$ of the unrefined rate (1/12.5 compared to $1 / 9)$. As illustrated by the additional royalty of R55 in table 5, any increase in the gross sales value or EBIT ratio as a result of beneficiation that is greater than the difference between the B-values could eradicate the benefit of a lower royalty rate. If the royalty rate formula in the MPRRA is used, the royalty on a refined mineral resource, compared to that of an unrefined mineral resource, will not only be affected by the difference in the B-inputs but also by the EBIT ratio as well as the gross sales value after beneficiation. Table 7 provides the royalty payable in terms of the MPRRA on the refined PGM for a series of changes in the EBIT and gross sales values as a result of beneficiation of the unrefined PGM (on which a royalty of R40.83 would be payable in terms of the MPRRA) in the hypothetical example. 
Table 7 Amount of royalty payable (in rand) on refined mineral resource in terms of the MPRRA for a series of changes in gross sales value and EBIT ratio to the information in the hypothetical fact pattern as a result of refinement

\begin{tabular}{|c|c|c|c|c|c|c|c|}
\hline & \multicolumn{6}{|c|}{ Increase in gross sales value as a result of refinement } \\
\hline & & $10 \%$ & $25 \%$ & $50 \%$ & $100 \%$ & $150 \%$ & $200 \%$ \\
\hline \multirow{6}{*}{ 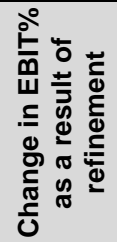 } & $-20 \%$ & 27.45 & 28.575 & 30.45 & 34.2 & 37.95 & 41.7 \\
\hline & $-10 \%$ & 29.85 & 30.975 & 32.85 & 36.6 & 40.35 & 44.1 \\
\hline & $0 \%$ & 32.25 & 33.375 & 35.25 & 39 & 42.75 & 46.5 \\
\hline & $20 \%$ & 37.05 & 38.175 & 40.05 & 43.8 & 47.55 & 51.3 \\
\hline & $50 \%$ & 44.25 & 45.375 & 47.25 & 51 & 54.75 & 58.5 \\
\hline & $100 \%$ & 56.25 & 57.375 & 59.25 & 63 & 66.75 & 70.5 \\
\hline
\end{tabular}

(A highlighted amount in bold type indicates that the royalty on the refined mineral resource exceeds the royalty on an unrefined mineral resource of $\mathrm{R} 40.83$ as shown in table 4 .)

Table 7 illustrates that the royalty on the refined mineral resource is likely to exceed the royalty on the unrefined mineral resource if the EBIT ratio or the gross sales value (or both) increases sufficiently as a result of beneficiation. It should be borne in mind that extractors will only further process mineral resources if the benefit (either the increase in EBIT ratio or gross sales value) is sufficient to compensate them for the further processing. The gross sales value and possibly also the EBIT ratio will therefore increase when a mineral resource is refined. Based on the information in table 7 , it is submitted that the royalty rates have to incorporate the $\mathrm{B}$ value differential as well as the changes in gross sales value and EBIT ratio as a result of beneficiation, to be effective in promoting downstream beneficiation. Since the royalty rate formula currently only provides a higher B-value, the MPRRA will not always result in the same royalty, irrespective of whether or not the mineral resource has been refined.

\section{Deduction of further processing costs from the royalty base}

An alternative to lower royalty rates for refined mineral resources is to determine the royalty base as the value of the mineral resource at a point before any beneficiation takes place to reflect the value at the point of extraction, as opposed to when it is transferred (National Treasury 2008a:5). By deducting processing costs from the gross sales value of the transferred mineral resource in order to arrive at such a value, the profit margin on the processing cost is not removed from the royalty base, resulting in a higher royalty base for a refined mineral resource. If this approach is combined with a royalty rate linked to a profit indicator (EBITDA or EBIT), any change in the profit indicator as a result of beneficiation will distort this amount. The impact of these discrepancies is illustrated by the additional royalty of R42 (table 5) charged in terms of the third bill where this approach was proposed. In addition to the ineffectiveness highlighted above, it was found that defining the point at which a mineral is in its readily saleable condition and allocating costs before and after this point can prove to be complex (Chamber of Mines of South Africa 2008). This complexity was the main reason why the MPRRA did not follow this approach as suggested in the third draft of the bill (National Treasury 2008a:5).

\section{Findings}

The comparison in table 5 and the royalties in table 7 show that the royalty mechanism in the MPRRA is unlikely to consistently result in the same royalty amount, 
irrespective of whether or not a mineral resource has been refined. Consequently, the MPRRA may be detrimental to the promotion of downstream beneficiation and be in contrast to the Mineral and Mining Policy of South Africa.

\section{Conclusions and recommendation}

The enactment of the MPRRA in 2008 introduced a royalty regime that could have a significant impact on the South African mining industry. The purpose of the article was to identify aspects of the MPRRA that could have a significant adverse impact on the South African mining industry, with a view to investigating these aspects further once the legislation has been effective for some time. To determine the potential impact of this royalty regime on the mining industry, it was critically analysed from the perspective of the state as custodian of the mineral resources, as well as from the perspective of the private mining companies that will extract the mineral resources.
The findings of the analysis suggest that the following aspects of the MPRRA may have an unintended adverse impact on the South African mining industry in future:

$\square$ The level of royalties to be levied may reduce extractors' profits to such an extent that it could affect their economic decisions on where to spend scarce exploration budgets.

$\square \quad$ In some instances, the legislation could result in higher mineral royalties on refined minerals than on unrefined minerals. This could discourage downstream beneficiation of mineral resources and result in the nation not obtaining maximum value from its nonrenewable resources.

This study contributes to the development of the South African mineral royalty regime by recommending aspects of the current royalty regime on which further research should be conducted to ensure that the regime achieves its broad objective of compensating the nation for the depletion of mineral resources, while encouraging exploration and maximising value addition.

\section{Bibliography}

Andrews-Speed, P. \& Rogers, C.D. 1999. Mining taxation issues for the future. Resources Policy, 25:221-227.

Cawood, F.T. 2004. The Mineral and Petroleum Resources Development Act of 2002: a paradigm shift in mineral policy in South Africa. The Journal of the South African Institute of Mining and Metallurgy, January/February 2004:53-64.

Cawood, F.T. 2007. An independent analysis of the 2006 draft royalty bill for the South African mineral and petroleum sectors. The Journal of the South African Institute of Mining and Metallurgy, 107, August:493-503.

Cawood, F.T. 2008. The 2007 South African Mineral and Petroleum Resources Draft Royalty Bill: an independent analysis. The Journal of the South African Institute of Mining and Metallurgy108, July:377-384.

Cawood, F.T \& Macfarlane A.S. 2003. The Mineral and Petroleum Royalty Bill - Report to National Treasury. The Journal of the South African Institute of Mining and Metallurgy, May:213-232. 
Chamber of Mines of South Africa. 2003. Submission to the National Treasury on the draft Mineral and Petroleum Royalty Bill. Unpublished document.

Chamber of Mines of South Africa. 2008. Submission to the National Treasury on the draft Mineral and Petroleum Royalty Bill. Unpublished document.

Chamber of Mines of South Africa. 2009. Annual Report 2008-2009. Unpublished document.

Competition Commission. 2003. Comments by the Competition Commission on the Mineral and Petroleum Royalty Bill. Unpublished document.

COSATU/NUM. 2003. Initial submission on the Draft Mineral and Petroleum Royalty Bill. Unpublished document.

Department of Minerals and Energy. 1998. A Minerals and Mining Policy for South Africa. October, Pretoria.

Garnaut, R. \& Clunnies Ross, A. 1983. Taxation of mineral rents. Oxford: Oxford University Press.

National Treasury. 2003. Press statement on the Mineral and Petroleum Royalty Bill. Issued on 20 March 2003

National Treasury. 2008a. Response document: Portfolio Committee on Finance, Mineral and Petroleum Resource Royalty Bill.

National Treasury. 2008b. Media statement: Mineral and Petroleum Resources Royalty Bills (Money Bill and Administration Bill), 4th and final draft. Issued on 3 June 2008.

National Treasury. 2009. Budget speech 2009.

O'Faircheallaigh, C. 1998. Indigenous people and mineral taxation regimes. Resources Policy, 24(4):187-198.

Otto, J., Andrews, C., Cawood, F., Doggett, M., Guj, P., Stermole, F., Stermole, J. \& Tilton J. 2006. Mining royalties: a global study of their impact on investors, government and civil society. Washington DC: The World Bank.

Revenue Watch Institute. 2008. Revenue Watch Institute: Submission to South African National Treasury - 28 February 2008. Unpublished document.

SAMDA, vide South African Mining Development Association.

South African Mining Development Association. 2003. Submission to the Department of Finance regarding the proposed mining royalty bill. Unpublished document.

Sharma. J.V.M \& Naresh, G. 2001. Mineral taxation around the world: trends and issues. AsiaPacific Tax Bulletin, January:2-10.

South Africa. 2002. Mineral and Petroleum Resources Development Act 28 of 2002. Government Gazette, 448(23922):1-122.

South Africa. 2003. Draft Mineral and Petroleum Royalty Bill.

South Africa. 2006. Draft Mineral and Petroleum Resources Royalty Bill.

South Africa. 2007. Draft Mineral and Petroleum Resources Royalty Bill.

South Africa. 2008a. Mineral and Petroleum Resources Royalty Bill.

South Africa. 2008b. Mineral and Petroleum Resources Royalty Act 28 of 2008. Government Gazette, 521(31635):1-13.

Stewart, T. 2008. Mining giants not convinced new Royalty bill will benefit them. Sowetan Newspaper, 27 August. 